\title{
ISOLATION AND CHARACTERIZATION OF NRCS-15, A NEW IRON-CONTAINING ANTIBIOTIC
}

\author{
BAKRY M. HAROUN \\ Microbial Chemistry Laboratory, National Research Centre, \\ Cairo, A. R. E.
}

(Received for publication July 3, 1973)

\begin{abstract}
A new iron-containing antibiotic named NRCS-15 was isolated from a Streptomyces strain. The antibiotic inhibits the growth of Gram-positive bacteria. The antibiotic is similar to the sideromycin group of antibiotics in that it contains iron but it differs in some other characters. Antibiotic NRCS-15 liberated 8 amino and 3 organic acids on hydrolysis. The morphological and physiological characteristics of the producing organism as well as the isolation and properties of the antibiotic are described.
\end{abstract}

A new iron-containing antibiotic has been isolated from the fermentation broth of Streptomyces NRC-S-15 by solvent extraction. It exhibits strong inhibitory activity against Gram-positive bacteria. Although a number of iron-containing antibiotics have been described, the physicochemical and biological properties of this compound (NRCS-15) indicate it to be a new antibiotic.

This paper deals with the characterization of streptomyces producing strain, the fermentation process, the isolation procedure and the properties of the antibiotic.

\section{Characteristics of the Antibiotic-producing Strain}

Streptomyces strain NRC-S-15 was isolated from a sandy soil collected at Riadh, Saudi Arabia. The morphology, cultural characteristics and the physiology of this strain was studied.

1. Morphological properties:

When the organism was grown on various media (Table 1) it formed aerial mycelia which developed into long spirals (Plate 2). The spores were oval with smooth surface lacking spines or hairs (Plate 2).

2. Cultural properties:

Cultural properties on various media ${ }^{1)}$ are listed in Table 1 .

Plate 1. Sporophores of Streptomyces NRC-S-15 $(\times 400)$

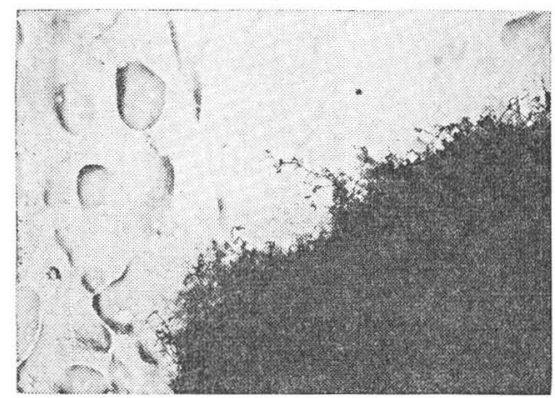

Plate 2. Electron micrograph of spores of Streptomyces NRC-S-15 $(\times 16,000)$

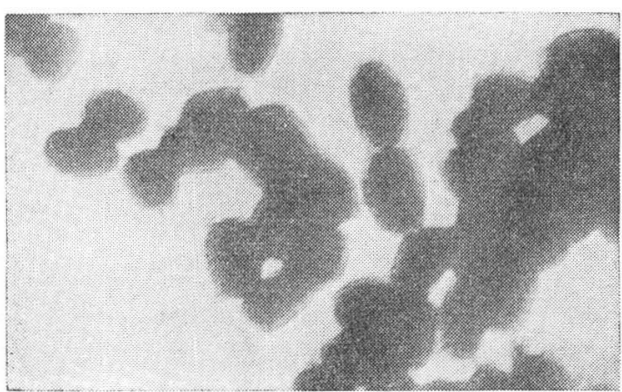


Table 1. Cultural properties of Streptomyces strain NRC-S-15 on various media*

\begin{tabular}{|c|c|c|c|}
\hline Medium & Growth & Aerial mycelium & Soluble pigment \\
\hline Starch-nitrate agar & deep gray growth & light powdery gray & straw yellow \\
\hline Sucrose-nitrate agar & $\begin{array}{l}\text { light brown } \sim \\
\text { reddish brown }\end{array}$ & light gray to deep gray & faint brown \\
\hline Glucose-nitrate agar & pink growth & powdery gray & pink \\
\hline Glucose-asparagine agar & purple growth & pale gray & none \\
\hline Glycerol-nitrate agar & dark brown & $\begin{array}{l}\text { white, later becoming } \\
\text { gray cottony }\end{array}$ & none \\
\hline $\begin{array}{l}\text { Glycerol-asparagine } \\
\text { agar }\end{array}$ & purple growth & deep gray & none \\
\hline Potato plug & reddish brown & deep gray & light brown \\
\hline Nutrient agar & deep gray & $\begin{array}{l}\text { white, later becoming } \\
\text { gray }\end{array}$ & none \\
\hline
\end{tabular}

* Observations were recorded after 14 days incubation at $28^{\circ} \mathrm{C}$

Table 2. Physiological properties of Streptomyces NRC-S-15 strain

\begin{tabular}{l|c}
\hline Production of hydrogen sulfide & - \\
Tyrosinase reaction & - \\
Reduction of nitrate & + \\
Coagulation of skimmed milk & - \\
Peptonization of skimmed milk & + \\
Liquefaction of gelatin & + \\
Cellulytic activity & - \\
\hline
\end{tabular}

Table 3. Utilization of carbon source by Streptomyces NRC-S-15 strain

\begin{tabular}{c|c}
\hline Utilization & Carbon source \\
\cline { 2 - 3 } Positive & $\begin{array}{c}\text { Glucose, frucose, maltose, lactose, } \\
\text { galactose, trehalose, mannitol } \\
\text { and starch }\end{array}$ \\
Noubtful & $\begin{array}{l}\text { Mannose, arabinose, sucrose, sor- } \\
\text { bose, Melibiose, cellobiose, sor- } \\
\text { bitol and sodium acetate } \\
\text { Raffinose, ribose and inulin }\end{array}$ \\
\hline
\end{tabular}

3. Physiological properties:

Physiological properties including the utilization of carbon sources ${ }^{2)}$, are summarized in Tables 2 and 3.

On the basis of these observations, the distinctive features of the strain are as follows: The mature aerial mycelium forms long spirals consisting of chains having smooth-surfaced oval spores. The colour of the vegetative growth on synthetic media is gray to deep gray to reddish brown. A straw yellow or reddish soluble pigment could be detected on various media.

4. Comparison of strain NRC-S-15 with related streptomycetes:

Streptomyces strain NRC-S-15 closely resembles the flavus series of streptomycetes based on its cultural characteristics. Consequently it was checked for identity with the known species of this group described by WAKSMAN ${ }^{3)}$. In view of this comparison (Table 4), NRC-S-15 strain appears to be most related to this series. However, on the basis of the information available it was not possible to assign it to a specific species.

\section{Production and Isolation}

Antibiotic NRCS-15 was produced in shaken flask culture incubated at $28^{\circ} \mathrm{C}$ on a rotary shaker at 200 r.p.m. The composition of the medium was $(\mathrm{g} /$ liter): soluble starch 1.5, glucose 1.0, $\mathrm{NaNO}_{3} 0.3, \mathrm{~K}_{2} \mathrm{HPO}_{4} 0.12, \mathrm{KCl} 0.08, \mathrm{MgSO}_{4} \cdot 7 \mathrm{H}_{2} \mathrm{O} 0.06$ and $\mathrm{FeSO}_{4} \cdot 5 \mathrm{H}_{2} \mathrm{O} 0.002$. The antibiotic content reached a maximum $(120 \mathrm{mg} /$ liter $)$ after $2 \sim 3$ days. 
Table 4. Comparison of strain NRC-S-15 with related Streptomyces species

\begin{tabular}{|c|c|c|c|c|c|}
\hline Organism & $\begin{array}{l}\text { Morphology on glucose } \\
\text { asparagine agar }\end{array}$ & Spirals & Spore surface & $\begin{array}{l}\text { Melanin } \\
\text { pigment }\end{array}$ & $\begin{array}{l}\text { Antimicro- } \\
\text { bial activity }\end{array}$ \\
\hline S. aureus & $\begin{array}{l}\text { Growth light orange, raised } \\
\text { center, hyaline margin. Aerial } \\
\text { mycelia light drab. }\end{array}$ & $\begin{array}{l}\text { Closed or open } \\
\text { spirals }\end{array}$ & $\begin{array}{l}\text { Spherical to } \\
\text { oval }\end{array}$ & + & + \\
\hline S. citreus & $\begin{array}{l}\text { Growth glossy olive yellow } \\
\text { center elevated. Aerial my- } \\
\text { celia white to pinkish }\end{array}$ & $\begin{array}{l}\text { Long narrow } \\
\text { open spirals }\end{array}$ & $\begin{array}{l}\text { Spherical to } \\
\text { oval }\end{array}$ & - & - \\
\hline S. alboflavus & $\begin{array}{l}\text { Growth restricted much fold- } \\
\text { ed, cream coloured with } \\
\text { sulfur-yellow surface. No. } \\
\text { aerial mycelia. No soluble } \\
\text { pigment }\end{array}$ & $\begin{array}{l}\text { Very little } \\
\text { tendency to } \\
\text { produce spirals }\end{array}$ & $\begin{array}{l}\text { Oval covered } \\
\text { by long fine } \\
\text { hairs }\end{array}$ & - & + \\
\hline S. flaveolus & $\begin{array}{l}\text { Aerial mycelia pale gray. } \\
\text { soluble gigment yellow green }\end{array}$ & $\begin{array}{l}\text { Short closed } \\
\text { and open } \\
\text { spirals } \\
\text { produced on } \\
\text { all media }\end{array}$ & $\begin{array}{l}\text { Oval to ellip- } \\
\text { tical covered } \\
\text { with long fine } \\
\text { hairs }\end{array}$ & - & + \\
\hline S. griseoflavus & $\begin{array}{l}\text { Growth citron yellow. Aerial } \\
\text { mycelia powdery greenish yel- } \\
\text { low changing to gray }\end{array}$ & $\begin{array}{l}\text { No spirals pro- } \\
\text { duced }\end{array}$ & $\begin{array}{l}\text { Spore oblong } \\
\text { covered with } \\
\text { short spines }\end{array}$ & - & + \\
\hline S. NRC-S-15 & $\begin{array}{l}\text { Aerial mycelia gray. No } \\
\text { soluble pigment }\end{array}$ & $\begin{array}{l}\text { Long monopo- } \\
\text { dially branch- } \\
\text { ing chains of } \\
\text { spirals }\end{array}$ & $\begin{array}{l}\text { Oval spores } \\
\text { with smooth } \\
\text { surface }\end{array}$ & - & + \\
\hline
\end{tabular}

The broth was harvested and extracted with chloroform at $\mathrm{pH} 8.0 \sim 8.5$. The extract was concentrated to a syrupy residue which was purified by dissolving it in a small volume of chloroform. The chloroform solution was chromatographed on an activated charcoal column which was developed with $70 \%$ aqueous ethanol. Active fractions were collected and concentrated in vacuo to an oily residue which was dissolved in methanol. An inactive white precipitate was removed by filtration. The methanol solution which contained the active fraction was evaporated until dry. The isolated product was dissolved in chloroform or ethyl acetate and precipitated out of solution with petroleum ether $\left(40 \sim 60^{\circ} \mathrm{C}\right)$.

\section{Physical and Chemical Properties}

Antibiotic NRCS-15 was obtained as an amorphous buff plates that melted at $149 \sim 150^{\circ} \mathrm{C}$. The results of the elemental analysis were: $\mathrm{C} 55.82, \mathrm{H} 6.33, \mathrm{~N} 8.08, \mathrm{Cl} 2.52$ and $\mathrm{Fe} 1.61 \%$. As shown in Fig. 1, the ultraviolet absorption spectrum of the antibiotic in $95 \%$ ethanol exhibits a peak at $210 \mathrm{~m} \mu\left(\left(\mathrm{E}_{1 \mathrm{~cm}}^{1 \%} 122.5\right)\right.$, in acidic ethanol $(95 \%$ ethanol $-0.1 \mathrm{~N} \mathrm{HCl})$, at $208 \mathrm{~m} \mu\left(\mathrm{E}_{1 \mathrm{~cm}}^{1 \%} 112.3\right)$, and in alkaline ethanol (95\% ethanol $-0.1 \mathrm{~N} \mathrm{NaOH})$ at $222 \mathrm{~m} \mu\left(\mathrm{E}_{1 \mathrm{~m}}^{1 \%} 1212.5\right)$.

The infrared spectrum of antibiotic NRCS-15 (Fig. 2) shows characteristic bands at 3400, 2950, $1660,1460,1360,1280,1250,1100,830$ and $750 \mathrm{Cm}^{-1}$. The $R_{f}$ values on descending paper chromatograms with different developing solvents are expressed in Fig. 3. Location of the zones occupied by the antibiotic was determined bioautographically using Bacillus subtilis as the test 
Fig. 1. Ultraviolet spectrum of antibiotic NRCS-15
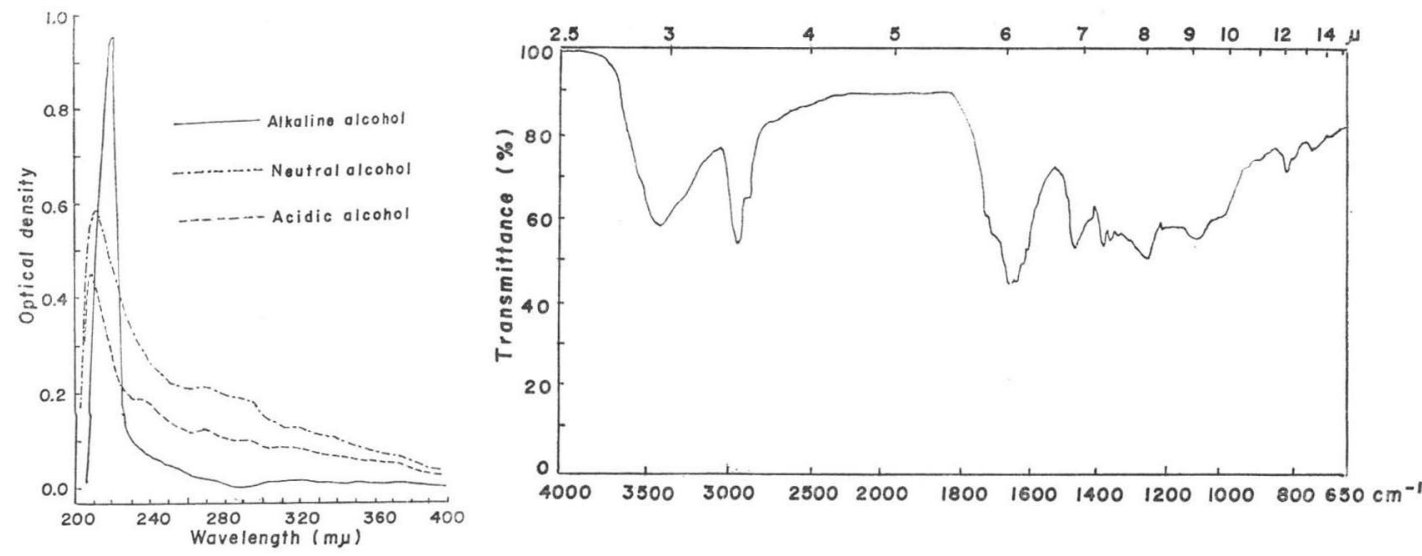

organism. One definite inhibition zone was always observed.

The antibiotic exhibits an indicator-like property, it is yellow in acid and turns red in alkaline solution. Antibiotic NCRS-15 is soluble in alcohols, esters, acetone and chloroform, slightly soluble in diethyl ether and insoluble in petroleum ether. The antibiotic gives positive results with ninhydrin, biuret, potassium thiocyanate, potassium ferrocyanide and nitration tests, and negative results with acid and alkaline $\mathrm{KMnO}_{4}$, MolisCH, FeHLING, Millon, Sakaguchi, ferric chloride and iodine solutions.

Eight amino acids and 3 organic acids were detected in the acid hydrolysate $(6 \mathrm{~N} \mathrm{HCl}$ at 105 ${ }^{\circ} \mathrm{C}$ for 24 hours) of the antibiotic. These acids were: lysine, aspartic acid, glutamic acid, threonine, alanine, tryptophan, valine, leucine, oxalic acid, tartaric acid and maleic acid. Tryptophan was detected in the alkaline hydrolysate (concentrated or saturated solution of barium hydroxide at $125 \sim 130^{\circ} \mathrm{C}$ ). These products were indentified when chromatographed by paper chromatography using Whatman No. 1 sheets and butanol-acetic acid-water (12:3:5) as the developing solvent.

\section{Biological Properties}

The antimicrobial spectrum of the antibiotic was obtained using agar diffusion and agar
Fig. 3. Behaviour of NRCS-15 when chromatographed with various developing solvents

\begin{tabular}{|c|c|}
\hline No. & Solvent used \\
\hline 1 & Petroleum ether \\
\hline 2 & Diethyl ether \\
\hline 3 & Butanol-petroleum ether- $\mathrm{H}_{2} \mathrm{O}(5: 2.5: 5)$ \\
\hline 4 & Ethyl acetate-petroleum ether- $\mathrm{H}_{2} \mathrm{O}(5: 2.5: 5)$ \\
\hline 5 & Chloroform $-\mathrm{H}_{2} \mathrm{O}(1: 1)$ \\
\hline 6 & $\mathrm{Na}_{2} \mathrm{CO}_{3}(0.5 \%)$ \\
\hline 7 & Butanol-acetic acid- $\mathrm{H}_{2} \mathrm{O}(4: 1: 5)$ \\
\hline 8 & $\mathrm{Na}_{2} \mathrm{HPO}_{4}(0.5 \%)$ \\
\hline 9 & Chloroform-petroleum ether- $\mathrm{H}_{2} \mathrm{O}(5: 2.5: 5)$ \\
\hline 10 & Methanol \\
\hline 11 & Ethyl acetate-petroleum ether- $\mathrm{H}_{2} \mathrm{O}(5: 2.5: 5)$ \\
\hline 12 & $\mathrm{NH}_{4} \mathrm{Cl}(3 \%)$ \\
\hline 13 & Chloroform-ethyl alcohol- $\mathrm{A}_{2} \mathrm{O}(5: 2.5: 5)$ \\
\hline 14 & $2 \mathrm{~N} \mathrm{HCl}$ \\
\hline 15 & Ethyl acetate \\
\hline 16 & Chloroform-ammonia $(1: 1)$ \\
\hline 17 & Ethyl acetate-acetic acid $(1: 1)$ \\
\hline 18 & $n$-Butanol \\
\hline 19 & Ethyl acetate-ammonia $(1: 1)$ \\
\hline 20 & Chloroform \\
\hline 21 & $\mathrm{H}_{2} \mathrm{O}$ \\
\hline 22 & Butanol-ethyl alcohol- $\mathrm{H}_{2} \mathrm{O}(5: 2.5: 5)$ \\
\hline 23 & Chloroform-acetic acid $(1: 1)$ \\
\hline
\end{tabular}

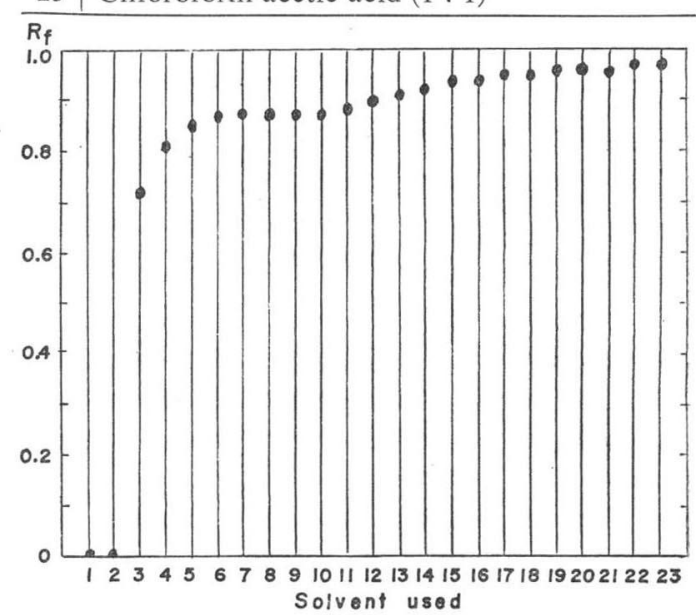


Table 5. Antimicrobial spectrum of NCR-S-15

\begin{tabular}{|c|c|c|c|}
\hline \multicolumn{2}{|l|}{ Agar diffusion method } & \multicolumn{2}{|l|}{ Agar dilution method* } \\
\hline Test organism & $\underset{(\mathrm{mcg} / \mathrm{ml})}{\text { M. I. C. }}$ & Test organism & $\begin{array}{l}\text { M. I. C. } \\
(\mathrm{mcg} / \mathrm{ml})\end{array}$ \\
\hline Bacillus subtilis ICC & 1.5 & Staphylococcus aureus FDA 209 P & 0.05 \\
\hline Bacillus subtilis $24 \mathrm{G}$ & 1.5 & Staphylococcus aureus Smith & 0.025 \\
\hline Bacillus subtilis $19 \mathrm{~T}$ & 3.12 & Staphylococcus aureus $\# 193$ & 0.05 \\
\hline Staphylococcus aureus NIHJ & 0.8 & Bacillus mycoides & 0.2 \\
\hline Staphylococcus aureus FDA 209 P & $<0.18$ & Bacillus sphericus & $<0.0003$ \\
\hline Saphylococcus aureus T-88 & 0.8 & Bacillus subtilis & $<0.0003$ \\
\hline Bacillus mycoides USSR & 12.5 & Escherichia coli $\mathrm{NIHJ}$ & 12.5 \\
\hline Escherichia coli NRRL-B-210 & $>100$ & Escherichia coli Juhl & 25 \\
\hline Escherichia coli NICB-8743 & $>100$ & Klebsiella pneumoniae & 6.3 \\
\hline Pseudomonas aeruginosa ATCC 14502 & $>100$ & Pseudomonas aeruginosa & 100 \\
\hline Lactobacillus acidophilus & 100 & Proteus vulgaris & 25 \\
\hline Mycobacterium phlei & $>100$ & Proteus mirabilis & 50 \\
\hline Sarcina lutea & $>100$ & & \\
\hline Saccharomyces cerevisiae NRRL-Y-567 & $>100$ & & \\
\hline Candida utilis & $>100$ & & \\
\hline Aspergillus niger & $>100$ & & \\
\hline Aspergillus terreus & $>100$ & & \\
\hline
\end{tabular}

* The agar dilution method was carried out at Bristol Laboratories.

dilution methods of assay (Table 5). NRCS-15 is primarily active against Gram-positive bacteria, weakly against Gram-negative bacteria and not active against yeast and molds.

It is of particular interest to note that the sideramine (ferrioxamine B) failed to antogonize the antimicrobial activity against Bacillus subtilis ICC strain of NRCS-15 (Plate 3), ASK-7534) and ferramidochloromycin (FACM) ${ }^{5)}$ (iron-containing antibiotics) while it did antagonize the activity of ferrimycin ${ }^{7)}$ and the antibiotic No. 22765 12 .

The antibiotic showed in vivo activity in mice infected intraperitoneally with Staphylococcus aureus Smith at $12.5 \mathrm{mg} / \mathrm{kg}$ with toxic manifestation at $60 \mathrm{mg} / \mathrm{kg}$. The subcutaneous $\mathrm{LD}_{50}$ was calculated to be $50 \mathrm{mg} / \mathrm{kg}$.

\section{Discussion}

Antibiotic NRCS-15 was isolated from a Streptomyces strain which appears to be closely related to the flavus series which differs in some morphological, cultural and physiological properties.

The antibiolotic has an indicator like property and in this respect it resembles mycorhodin $^{8)}$ which have this character but the

Plate 3. Antimicrobial effects of ferrimycin, Antibiotics NRC-S-15, ASK-753 and 22765 in presence of ferrioxamine B

Test organism: Bacillus subtilis, ICC strain

\begin{tabular}{|c|c|c|c|}
\hline \multicolumn{4}{|c|}{ Strip A loaded with ASK-753 } \\
\hline$" \mathrm{~B}$ & $" \prime$ & $"$ & NRC-S-15 \\
\hline $\mathrm{C}$ & " & " & Ferrimycin* \\
\hline$" \mathrm{D}$ & $" \prime$ & " & $22765 *$ \\
\hline$" \mathrm{E}$ & $"$ & $"$ & ferrioxamine $B$ \\
\hline
\end{tabular}

* These substances were kindly offered by Dr. H. BICKEL, assistant manager, Ciba Ltd., Switzerland

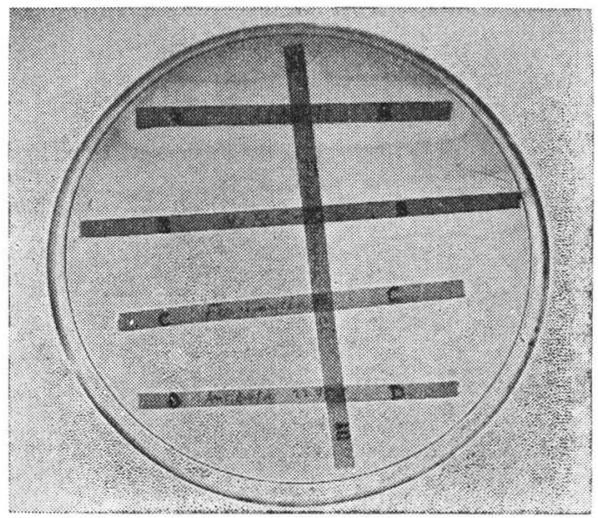


two compounds differ in their physicochemical and biological properties.

Antibiotic NRCS-15 is freely soluble in water and most organic solvents, but hardly soluble in diethyl ether and insoluble in petroleum ether. On acid and alkaline hydrolyses the antibiotic yields 8 amino and 3 organic acids which differentiate it from other polypeptide iron-containing antibiotics.

NRCS-15 is unique among the iron-containing peptide antibiotics in that it resembles members of sideromycin antibiotics ${ }^{7 \sim 12)}$ in being a water-soluble polypeptide containing iron. However, it differs from this group in its acid-base character, aromatic nature and chlorine content. Its antimicrobial activity is not antagonized by ferrioxamine B. For these reasons NRCS-15 is considered as a new iron-containing antibiotic.

\section{Acknowledgement}

The author wishes to express his gratitude to Dr. Maxwell Gordon, Director of Research Planning, Bristor Laboratories, Syracuse, New York, for the valuable help which he offered regarding the in vitro and in vivo evaluation of the antibiotic.

Thanks are alos due to Dr. SAmir, M. BADR, El Din, Microbial Chemistry Laboratory, National Resaarch Center, for his discussion of this manuscript.

\section{References}

1) Waksman, S. A.: The actinomycetes. Vol. 2, Chapter 8. Description of species, pp. 165 222. The Williams and Wilkins Co., Baltimore, 1961

2) Pridham, T.G. \& D. Gottlieb: The utilization of carbon compounds by some Actinomycetales as an aid for species determination. J. Bact. $56: 106 \sim 114,1948$

3) Waksman, S. A.: The actinomycetes. pp. 115 134. The Ronald Press Company, 1967

4) Shimi, I. R.; G. M. Imam \& B. M. Haroun: ASK-753, a new iron-containing antibiotic. J. Antibiotics $22: 106 \sim 111,1969$

5) Shimi, I. R. \& S. Shoukry: Ferramido chloromycin, a new antibiotic. J. Antibiotics, Ser. A 19 : $110 \sim 114,1966$

6) Misiek, M.; A. Gourevitch, B. Heinemann, M. J. Cron, D. F. Whitfhead, H. Schitiz, I. R. HOOPER \& J. LeIN: Mycorhodin, a new antibiotic. Antibiot. \& Chemoth. $9: 280 \sim 285,1959$

7) Bickel, H.; E. Gäumann, G. Nussberger, P. Reusser, E. Vischer, W. Voser, A. Wettstein \& H. ZÄHNER: Stoffwechselprodukte von Actinomyceten. Über die Isolierung und Charakterisierung der Ferrimycine $\mathbf{A}_{1}$ und $\mathbf{A}_{2}$, neue Antibiotika der Sideromycin-Gruppe. Helvet. Chim. Acta $43: 2105 \sim$ 2118,1960

8) Umezawa, H.: Recent advances in chemistry and biochemistry of antibiotics. Inst. Microb. Chem., Tokyo, 1964

9) Kuehl, F. A., Jr.; M. N. Bishop, L. Chaiet \& K. Folkers: Isolation and some chemical properties of grisein. J. Am. Chem. Soc. 73 : 1770 1773, 1951

10) GAuse, G. F.: Recent studies on albomycin, a new antibiotic. Brit. Med. J. 1995-2 : 1177 1179, 1955

11) ZähneR, H.; R. HütTer \& E. BAchmann: Stoffwechselprodukte von Actinomyceten. XXIII. Zur Kenntnis der Sideromycinwirkung. Arch. Mikrobiol. 36 : 325 349, 1960

12) Bickel, H.; E. Gäumann, W. Keller-Schieriein, V. Prelog, E. Vischer, A. Wettstein \& H. Zähner: Über eisenhaltige Wachstumsfaktoren, die Sideramine, und ihre Antagonisten, die eisenhaltigen Antibiotika Sideromycine. Experimentia, $16: 128 \sim 133,1960$ 